\title{
Test Anxiety is Reviewed By Gender
}

\author{
Kusmawaty Matara ${ }^{1}$, Eka Apristian Pantu ${ }^{2}$ \\ Institut Agama Islam Negeri (IAIN) Sultan Amai Gorontalo, Gorontalo Province, Indonesia ${ }^{1,2}$ \\ \{kusmawaty@iaingorontalo.ac.id ${ }^{1}$, ekapantu@iaingorontalo.ac.id² $\}$
}

\begin{abstract}
Facing the final exam is a frightening specter for every student. The fear of failing in exams causes students to experience test anxiety. This study aims to examine differences in test anxiety in terms of gender. The subjects in this study were 255 students in Indonesia. This research used test anxiety inventory as instrument. The results of the analysis showed that the mean of test anxiety in facing exams on male subjects was 3.10, while the mean of test anxiety in facing exams on female subjects was 3.35. The results of this study indicate that there is a significant difference in test anxiety in facing exams in male and female subjects.
\end{abstract}

Keywords: Test Anxiety; Students; Gender

\section{Introduction}

The final test was frightening for students. Determining the fate of students as if only determined by the final exam made students experience fear of the exam process. The fear of failing the exam caused students to experience test anxiety. Test anxiety was a feeling of uneasiness experienced by students before an exam. Test anxiety was usually caused by a lack of student self-esteem [1].

Test anxiety was found in students at the Faculty of Medicine, University of Andalas when having Objective Structured Clinical Examination (OSCE) [2]. In addition, in a study conducted by Apriliana, it was found that $37.5 \%$ of SMK Kuta students experienced high anxiety in facing computer-based national exams while $7.5 \%$ reported high anxiety [3]. The higher the test anxiety shown, the lower the test score obtained by the individual in the exam [4].

Test anxiety would provide its own problems for individuals. In a study conducted by Rana and Mahmood [5], it was found that test anxiety could be the cause of students showing low academic achievement when compared to the individual's actual abilities. In another study conducted by Khailala it showed that there was a negative relationship between test anxiety and individual academic achievement [6]. Another study conducted by Apriliana [7] found that individuals with test anxiety showed a pale face, irritable emotions, irritability, anxiety, and deep breaths [8].

The anxiety shown by individuals had a close relationship with individual self-efficacy [9]. Individuals with high self-efficacy had the belief that they were capable of completing a task well. The feeling of being able to complete a task well would reduce the level of anxiety you had. Conversely, individuals with low self-efficacy felt unsure about carrying out a task so that this feeling of uncertainty would cause individuals to experience anxiety [10]. 
Test anxiety could occur due to external factors such as the difficulty of the material being tested [11]. The difficulty of the material being tested made individuals doubted their abilities and had feelings of fear if they failed the test. The more difficult the exam material was, the higher the individual test anxiety would be. In addition, test anxiety could also occur because of pressure from parents [12]. High pressure from parents to children would become a burden for children so that they were afraid if they failed the test. This could increase students' anxiety in facing exams.

Apart from external factors, test anxiety could also be caused by internal factors such as self-efficacy [13]. The higher the self-efficacy you had, the lower your test anxiety would be. Conversely, for individuals with low self-efficacy, the test anxiety they had would be even higher. Another factor that could cause individuals to experience test anxiety was the selfesteem they had [14]. A study conducted by Putwain and Daly [15] found that females in the UK had higher test anxiety when compared to males. This was further strengthened by research conducted by Stoeber which found that there were significant differences in test anxiety between males and females [16].

Gender was considered a factor in the occurrence of test anxiety. In a study conducted by McCormick and O'Connor [17], it was found that women who had conflicts showed lower learning abilities and achievements when compared to boys who had conflicts. Lack of ability caused an individual female to worry about the tests they would face. The greater the feeling of worrying that was owned, the greater the tendency of the individual to experience anxiety in the exam [18]. Meanwhile, in another study conducted by Saputra and Widayanti [19] which was conducted on class X students of SMA Negeri 2 Ungaran, it was found that there was no significant difference in academic anxiety when viewed from gender. Academic anxiety was how the physical, psychological, and behavioral responses were shown in facing the pressure of completing the academic tasks [20].

The findings that had been there being interesting to be researched again. Where in two studies that occurred in Europe, it was found that there were differences in the level of test anxiety where females reported higher test anxiety [21] [22]. Meanwhile, in a study conducted by Saputra and Widayanti [23], it was found that gender differences did not have a significant effect on academic anxiety. The academic anxiety variable which was more common when compared to test anxiety was suspected to have an insignificant effect on the role of gender on academic anxiety. Based on this, it was interesting to examine how test anxiety was reviewed based on gender.

Based on the description above, this study aims to examine whether there is a difference in test anxiety in terms of gender. Meanwhile, the benefits that can be obtained in research are enriching references about test anxiety so that prevention and management efforts for individuals who experience test anxiety can be carried out effectively and efficiently.

\section{Test Anxiety and Gender}

Test anxiety is anxious feelings experienced by individuals when facing a test. Nurfitri and Muldayanti [24] explained that one of the factors was anxiety due to difficult material. The difficulty of the material to be tested had a negative relationship with individual selfefficacy so that the lower the self-efficacy of the individual, the greater the test anxiety they had [25]. Research conducted by Schuch, Roest, Nolen, Penninx, and Jonge [26] stated that females experienced more anxiety when compared to males. Females experienced anxiety in many conditions including when faced with the exams [27]. 
Test anxiety had a negative relationship with individual academic achievement [28]. Females showed significantly higher anxiety when compared to males [29]. One of the factors that caused women's anxiety to be higher was the self-esteem factor. Male was reported to have better self-esteem when compared to female [30]. As a result, the female will show higher test anxiety when compared to male.

Based on the existing theoretical description, there are two hypotheses in this study, namely: 1) There is a significant difference in the value of test anxiety in males and females, and 2) Females have higher test anxiety when compared to males.

\section{Methodology}

\subsection{Research Design}

This research was conducted with a comparative quantitative approach. This approach was chosen because data collection was carried out using a distributed scale and then comparisons were made between subjects with male and female.

\subsection{Participants}

This study tested the level of test anxiety in students in terms of gender. The total number of participants who filled out the scale and analyzed the data was 255 people with details of 114 male subjects and 141 female subjects consisting of students in Indonesia. The choice of students as the main subject in this study was because test anxiety did not only occur in school students but also in students who were considered more ready to face exams [31].

\subsection{Research Instruments}

This research used a test anxiety inventory scale developed by Taylor and Deane [32]. This scale consisted of eight items and had been adapted into Indonesian. When try out was carried, the reliability value of this scale was 0.82 .

\subsection{Research Data Analysis}

The data analysis technique used in this study was the independent sample t-test using the SPSS software. This technique aimed to test whether there was a significant difference in test anxiety in male and female subjects and to find out who had the higher test anxiety between the two.

\section{Results and Discussion}

Table 1. The Results of the Independent Sample t-test

\begin{tabular}{lcc}
\hline & Levene test (p) & t-test (p) \\
\hline Equal variances assumed & 0.268 & 0.008 \\
Equal variances not assumed & & 0.009 \\
\hline
\end{tabular}


Based on the results of the analysis using the Levene test, a probability value was obtained of 0.268 . This indicated that the population variants were identical. Meanwhile, the t-test results showed a probability of 0.008 , which meant that there was a significant difference in test anxiety between the two groups. These results indicated that the first hypothesis in this study was accepted.

Table 2. The Compare Mean Results

\begin{tabular}{ccc}
\hline Gender & $\mathbf{N}$ & Mean \\
\hline Male & 114 & 3,104 \\
Female & 141 & 3,350 \\
\hline
\end{tabular}

Meanwhile, the mean test showed the mean of test anxiety in male subjects was 3.10, while the mean of test anxiety in female subjects was 3.35. This was following the second hypothesis in this study, namely, that females had higher test anxiety than males.

The first hypothesis that was successfully proven in this study was a significant difference in test anxiety between males and females. Meanwhile, the second hypothesis in this study that females had higher test anxiety than males was also proven. This was following the research conducted by Sari, Bilek, and Celik[33], and Sari, Mudjiran, and Alizamar[34] who found that there were significant differences in test anxiety between male and female, where female reported a higher test anxiety score when compared to male.

The acceptance of the two hypotheses in this study could be explained by several factors. The first factor that affected the significant differences in test anxiety between the gender was the self-esteem factor. In a longitudinal study conducted from 1988 to 2018, it was found that self-esteem was a very strong predictor of predicting test anxiety[35]. One of the factors related to self-esteem was a masculine character[36]. The masculine character possessed by males made them having better self-esteem than females. This had an impact on the high test anxiety experienced by females when compared to males.

Apart from the self-esteem factor, another factor that caused the hypothesis in this study to be accepted was the academic self-efficacy factor. Each increase in academic self-efficacy could have an effect on individual test anxiety scores[37]. Females were reported to perceive themselves as having weaknesses in academic terms when compared to males who have the same learning achievement as him[38]. This feeling of weakness made academic self-efficacy in females lower than males and had an impact on the test anxiety felt by females and males.

The achievement motivation factor was also one of the causes of female test anxiety which was significantly higher than male test anxiety. Female had greater achievement motivation than male, especially in the aspects of extrinsic motivation, personal goals, attitudes, and motivational strength[39]. The amount of achievement motivation that females had, it would be a separate pressure for them to prove that they could complete the on-going exams[40]. The pressure to prove themselves experienced makes females feel greater test anxiety when compared to males.

\section{Conclusion}

Based on the research conducted, it can be concluded that: a) there are significant differences in the value of test anxiety in males and females, b) Females show higher test anxiety when compared to males. Self-esteem, self-efficacy, and achievement motivation are factors that influence this. 
The implication in this study was that the authorities paid more attention to the test anxiety variable because test anxiety had a close relationship with the required learning achievement. A comprehensive learning evaluation needs to be done because not all students could control themselves properly when facing exams. Suggestions for future researchers who wanted to research about test anxiety could use other variables outside of gender. In addition, it could also conduct testing using variables of age and education level as moderating variables between masculinity and feminism with test anxiety.

\section{References}

[1] Alam, M. D. (2013). A Study of Test Anxiety, Self Esteem, and Academic Performance Among Adolescence. IUP Journal of Organizational Behavior, 12(4), 33 43.

[2] Amir, D. P., Iryani, D., \& Isrona, L. (2016). Hubungan Tingkat Kecemasan dalam Menghadapi bjective Structured Clinical Examination (OSCE) pada Mahasiswa Fakultas Kedokteran Universitas Andalas. Jurnal Kesehatan Andalas, 5(1), 139-144.

[3] Apriliana, I. P. (2018). Tingkat Kecemasan Siswa SMK Menghadapi Ujian Nasional Berbasis Komputer Tahun 2018. Counselia: Jurnal Bimbingan dan Konseling, 8(1), 37-44.

[4] Zhang, N., \& Henderson, C. N. (2014). Test Anxiety and Academic Performance on Chiropratic Students. the Journal of Chiropractic Education, 28(1), 2-8.

[5] Rana, R. A., \& Mahmood, N. (2010). the Relationship Between Test Anxiety and Academic Achievement. Bulletin of Education and Research, 32(2), 63-74.

[6] Khailala, R. (2015). the Relationship Between Academic Self-Concept, Intrinsic Motivation, Test Anxiety, and Academic Achievement among Nursing Students: Mediating and Moderating Effects. Nurse Education Today, 35, 432-438.

[7] Apriliana, I. P. (2018). Tingkat Kecemasan Siswa SMK Menghadapi Ujian Nasional Berbasis Komputer Tahun 2018. Counselia: Jurnal Bimbingan dan Konseling, 8(1), 37-44.

[8] Apriliana, I. P. (2018). Tingkat Kecemasan Siswa SMK Menghadapi Ujian Nasional Berbasis Komputer Tahun 2018. Counselia: Jurnal Bimbingan dan Konseling, 8(1), 37-44.

[9] Soysa, C. K., \& Wilcomb, C. J. (2015). Mindfulness, Self-Compassion, Self-Efficacy, and Gender as Predictors of Depression, Anxiety, Stress, abd Well Being. Mindfulness, 217-226.

[10] Permana, H., Harahap, F., \& Astuti, B. (2016). Hubungan Antara Efikasi Diri dengan Kecemasan dalam Menghadapi Ujian pada Siswa Kelas IX di MTS Al Hikmah Brebes. Hisbah, 13(1), 51-68.

[11] Nurfitri, \& Muldayanti, N. D. (2018). Analisis Tingkat Kecemasan Siswa Menghadapi Ujian Akhir Semester pada Mata Pelajaran IPA Kelas VIII MTS. Raudlatul Firdaus. Jurnal Bioeducation, 5(1), 1-7.

[12] Nurfitri, \& Muldayanti, N. D. (2018). Analisis Tingkat Kecemasan Siswa Menghadapi Ujian Akhir Semester pada Mata Pelajaran IPA Kelas VIII MTS. Raudlatul Firdaus. Jurnal Bioeducation, 5(1), 1-7.

[13] Permana, H., Harahap, F., \& Astuti, B. (2016). Hubungan Antara Efikasi Diri dengan Kecemasan dalam Menghadapi Ujian pada Siswa Kelas IX di MTS Al Hikmah Brebes. Hisbah, 13(1), 51-68. 
[14] Alam, M. D. (2013). A Study of Test Anxiety, Self Esteem, and Academic Performance Among Adolescence. IUP Journal of Organizational Behavior, 12(4), 3343.

[15] Putwain, D., \& Daly, A. L. (2014). Test Anxiety Prevalence and Gender Differences in Sample of English Secondary School Students. Educational Studies, 40(5), 554-570.

[16] Stoeber, J. (2004). Dimensions of Test Anxiety: Relations to Ways of Coping with Pre Exam Anxiety and Uncertainty, Anxietym Stress, \& Coping. an International Journal, 17(3), 213-226.

[17] McCormick, M. P., \& O'Connor, E. E. (2015). Teacher-Child Relationship Quality and Academic Achievement in Elementary School: Does Gender Matter? Journal of Educational Psychology, 107(2), 502-516.

[18] Rana, R. A., \& Mahmood, N. (2010). the Relationship Between Test Anxiety and Academic Achievement. Bulletin of Education and Research, 32(2), 63-74.

[19] Saputra, D. N., \& Widayanti, C. G. (2014). Perbedaan Kecemasan Akademis ditinjau dari Jenis Kelamin pada Kelas X SMA Negeri 2 Ungaran. Empati, 3(3), 1-10.

[20] Saputra, D. N., \& Widayanti, C. G. (2014). Perbedaan Kecemasan Akademis ditinjau dari Jenis Kelamin pada Kelas X SMA Negeri 2 Ungaran. Empati, 3(3), 1-10.

[21] Stoeber, J. (2004). Dimensions of Test Anxiety: Relations to Ways of Coping with Pre Exam Anxiety and Uncertainty, Anxietym Stress, \& Coping. an International Journal, 17(3), 213-226.

[22] Putwain, D., \& Daly, A. L. (2014). Test Anxiety Prevalence and Gender Differences in Sample of English Secondary School Students. Educational Studies, 40(5), 554-570.

[23] Saputra, D. N., \& Widayanti, C. G. (2014). Perbedaan Kecemasan Akademis ditinjau dari Jenis Kelamin pada Kelas X SMA Negeri 2 Ungaran. Empati, 3(3), 1-10.

[24] Nurfitri, \& Muldayanti, N. D. (2018). Analisis Tingkat Kecemasan Siswa Menghadapi Ujian Akhir Semester pada Mata Pelajaran IPA Kelas VIII MTS. Raudlatul Firdaus. Jurnal Bioeducation, 5(1), 1-7.

[25] Permana, H., Harahap, F., \& Astuti, B. (2016). Hubungan Antara Efikasi Diri dengan Kecemasan dalam Menghadapi Ujian pada Siswa Kelas IX di MTS Al Hikmah Brebes. Hisbah, 13(1), 51-68.

[26] Schuch, J. J., Roest, A. M., Nolen, W. A., Penninx, B. W., \& Jonge, P. d. (2014). Gender Differences in Major Depressive Disorder: Results from the Netherlands Study of Depression and Anxiety. Journal of Affective disorders, 156, 156-163.

[27] Putwain, D., \& Daly, A. L. (2014). Test Anxiety Prevalence and Gender Differences in Sample of English Secondary School Students. Educational Studies, 40(5), 554-570.

[28] Zhang, N., \& Henderson, C. N. (2014). Test Anxiety and Academic Performance on Chiropratic Students. the Journal of Chiropractic Education, 28(1), 2-8.

[29] Stoeber, J. (2004). Dimensions of Test Anxiety: Relations to Ways of Coping with Pre Exam Anxiety and Uncertainty, Anxietym Stress, \& Coping. an International Journal, 17(3), 213-226.

[30] Bleidorn, W., Arslan, R. C., Denissen, J. J., Rentfrow, P. J., Gebauer, J. E., Potter, J., \& Gosling, S. D. (2016). Age and gender differences in self-esteem: A cross-cultural window. Journal of Personality and Social Psychology, 111(3), 396-410.

[31] Orfus, S. (2008). the Effect Test Anxiety and Time Pressure on Performance. the Huron University College Jurnal of Learning and Motivation, 46(1), 118-133.

[32] Taylor, J., \& Deane, F. P. (2002). Development of a Short Form of the Test Anxiety Inventory (TAI). the Journal of General Psychology, 129(2), 127-136. 
[33] Sari, S. A., Bilek, G., \& Celik, E. (2018). Test anxiety and self-esteem in senior high school students: a cross-sectional study. Nordic Journal of Psychiatry, 72(2), 84-88.

[34] Sari, A. W., Mudjiran, \& Alizamar. (2017). Tingkat Kecemasan Siswa dalam Menghadapi Ujian Sekolah Ditinjau dari Jenis Kelamin, Jurusan dan Daerah Asal Serta Implikasi. Jurnal Bikotetik, 1(2), 37-72.

[35] Embse, N. v., Jester, D., Roy, D., \& Post, J. (2018). Test Anxiety Effects, Predictors, and Correlates: A 30-year meta-analytic review. Journal of Active Disorders, 227, 483493.

[36] Burnett, J. W., Anderson, W. P., \& Heppner, P. P. (1995). Gender Roles and SelfEsteem: A consideration of enviromental factors. Journal of Counseling and Development, 73(3), 323-326.

[37] Krispenz, A., Gort, C., Schultke, L., \& Dickhauser, O. (2019). How to Reduce Test Anxiety and Academic Procrastination Through Inquiry of Cognitive Appraisals: A pilot study investigating the role of academic self-efficacy. Frontiers in Psychology, $10,1-14$.

[38] MacPhee, D., Farro, S., \& Canetto, S. S. (2013). Academic Self-Efficacy and Performance of Underrepresented STEM Majors: Gender, Ethnic, and Social Class Patterns. Analysis of Social Issue and Public Policies, 13, 347-369.

[39] Becirovic, S. (2017). The Relationship Between Gender, Motivation and Achievement in Learning English as A Foreign Language. European Journal of Contemporary Education, 6(2), 210-220.

[40] Syafrizal, \& Fadilah, N. (2018). Students' Test Anxiety in English Foreign Learners in Indonesian Context. English Education, 3(1), 8-34. 